Global Conferences Series:

Social Sciences, Education and Humanities (GCSSSEH), Volume 3, 2019

The $1^{\text {st }}$ International Conference on Education, Social Sciences and Humanities

DOI: https://doi.org/10.326/hum0199

\title{
Promoting Deep Learning in EFL Context: How Students Work Together in Creating Book
}

\author{
Desiani Natalina Muliasari ${ }^{1}$, Winti Ananthia ${ }^{2}$ \\ 1,2 Universitas Pendidikan Indonesia, Bandung, Indonesia, \\ (*) $\square$ desianinm@upi.edu
}

\begin{abstract}
The study investigates how students work together in creating book. The study focus on how the students negotiate ideas to solve problems emerged in creating book. Creating book is one of the project to promote deep learning. Deep learning is one of the basic skill that should be acquired by an Individual as early as possible. The study is qualitative study. It involved first grade students of primary school consist of 24 boys and 26 girls. The result shows that the students negotiate their ideas based on three problems in book project, and those were deciding book title, sharing responsibilities of deciding the flow of the book and deciding the book cover.
\end{abstract}

Keywords: Deep learning, EFL context, Creating Book

\section{Introduction}

Deep learning is a life long learning as it is connected the factual knowledge and the real world experiences (Ohlsson, 2011; Fullan \& Langworthy, 2014) . Through this connection an individual is able to grasp the implications. Thus deep learning is necessary for individual to acquire as early as possible. Elementary school is becoming a target as it is considered as a starting point of formal education (Muliasari, 2017). Moreover, Deep learning gives an opportunity to built partnership between teachers and students. (Fullan \& Langworthy, 2014). Creating book is a project based learning and it is considered as an alternative to create deep learning. Project-based learning (PjbL) involved students to design a project, investigate and solve problems, as it is create and increase collaboration between students (Ahsan, 2005; Hung, Hwang \& Huang, 2012; Turtyantana, 2013, Ruwaida, et.al, 2018). Additionally, children are motivated to explore, evaluate, interpret and synthesize some information in producing learning outcome or products (Kemendikbud, 2014). It is a students' center instruction arranged by students' independence, constructive inquiry, goal-setting, collaboration, communication and reflection in realistic condition (Kokotsaki, Menzies, Wiggins, 2016). Moreover through project based learning the students have the opportunities to get into deep learning in terms of relating new ideas to the prior knowledge and relating concepts to everyday experiences (Tan, 2013).

Unfortunately, the learning process specifically in the context of the English as foreign language in Indonesia tended to have surface learning. The teaching and learning process showed translating from Bahasa Indonesia into the target language; English, and memorizing. It only practiced the cognitive development without considering other skills. Thus, deep learning in the cotext of EFL in

Copyright $@$ ( 2019, the Authors. Published by Redwhite Press. 
Indonesia for children needed to be improved in order to have the students' experienced the language and applied it in everyday life. The purpose are the students having practice English and acquiring other skills such as problem solving, negotiating ideas and appreciate others.

\section{Method}

The study was conducted to improve the students' speaking skill through story dication. And it was a part of bigger research related to children's critical thinking. However, this paper is only focused on how students were communicating their ideas in solving the problems of a book project. This study is qualitative as the research would like to find out a deeper understanding on how students of first garde of elementary schools exchange ideas. The participant of the study were first grade students of elementary school. It involved 24 boys and 26 girls of two different classes of one private school in Bandung Indonesia. The data were collected through observation, Interview and field notes.

This article focuses discussion on the three problems in creating the book. Those were deciding the book title, sharing responsibilities of deciding the flow of the book, deciding the book cover. Thus the data analysis were based on the three items mentions above. The reserach also limited to the "food" theme as the students were in the middle of learning the theme.

\section{Results and Discussion}

The article focuses on how students the discussed to solve the problem of deciding book title, sharing responsibilities of deciding the flow of the book and deciding the book cover. The book project was an activity in EFL context. The theme of the book project was "Food" and the English vocabulary focused on the "food" that were familiar for students. The data revealed that the process of discussion in creating the book was in Bahasa Indonesia, but the targetted vocabularies was in English as the target language. The students were devided into groups of five and each of the group produced one book and one title. The process of discussion became the focus in the article as it revealed how the students worked with their peers and teacher. The findings would be discussed below based on the problems' stages,

Deciding the title of the book

In this step, the teacher first lead the discussion. The teacher asked the students to inventarize the students favorite food in a piece of paper. They should the most favorite one from the list they made. After that the students discussed in a group their most favorite food and they should come up with one food as the title of the book. The discussion revealed that some students in some groups tend to have a peace discussion. There were no arguments, and accepted what the teacher's suggested of what they did. For example when some students needed time to think and they had run out of the time, the teacher suggested some choices. The students tehn accepted the first choice without any arguments. On the other hand, there were groups that each of the member emerged with different title for example noodle, pizza and ice cream. And they kept trying their ideas to be accepted by peers in the group. Thus the teacher should make the member of the group voted for the title based on their experiences of their everyday life. It was seen from what the teacher asked the students,

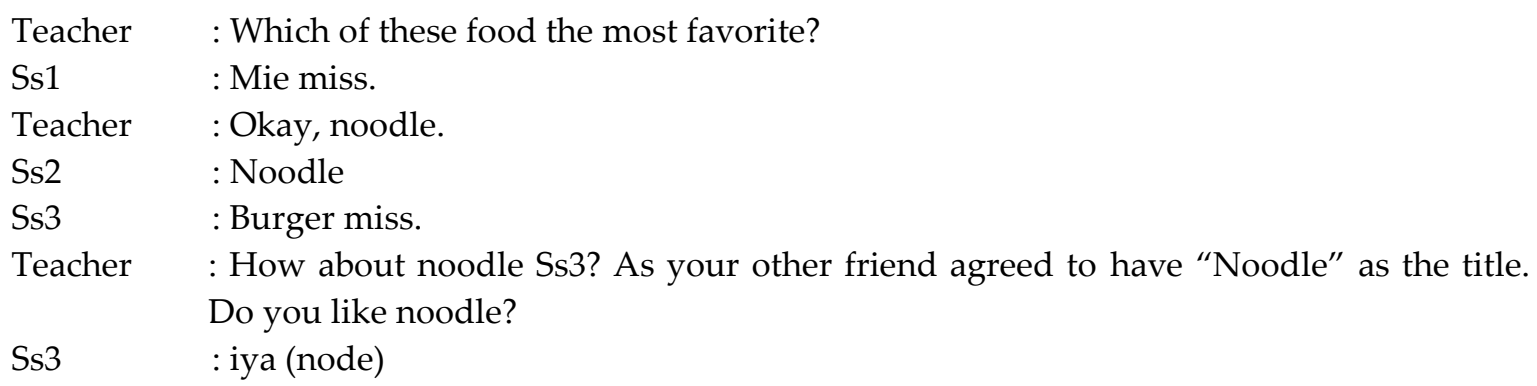


Teacher : Okay with the noodle?

Ss3 responsed the teacher question by nodding of agreement.

The scene described that the students basically practiced to negotiate meaning and to have more than just expressing ideas but how they accepted other ideas and managed to have arguments. Though at first one girl disagreed. But after she gave a chance to think about "noodle" she finally agreed based on her experience. Moreover the data also revealed that one group extended an independent discussion and they considered the peers in the group. When the group almost chose soup for the topic of the storybook, one of the students realised that one of the members of the group did not like it. He then initiatively took control in the group and led the group to find another food that was liked by all the group members. He said that they could not choose a particular food when someone in the group did not like it. Therefore they discussed to choose another food, and they came to an agreement to choose ice cream as the topic of their storybook.

Sharing responsibilities in deciding the flow of the Book

There were two classes involved in the study and it came up with different culture of the class; Jupiter class and saturn Class. Both classes offer responsibilities to find out further information about the food; the size, ingredients, taste, how to make it, the best time to eat it and why they like it. Each of the group had to find the information and each member of the group should decide what information they have to find out and draw any relevant picture with the information. The students in Jupiter class tended to choose focus only to one information. Meanwhile the students in Saturn class would love to have more than one information to find out. This assignment was then discussed at the second meeting. In sharing the information responsibilities, the teacher first told that they should decide whose to which information. The students did not have long discussion. They chose and the other accepted willingly.

The second meeting, the studets should decide the five information related to the size, ingredients, taste, how to make it, the best time to eat it and why they like it and the drawing into pages. Which drawing and information should become the first, the second, and so on pages. Some groups showed another peace discussion. For example, there was one studen lead the discussion in the group and others accepted without no doubt. In the Jupiter class, there was a time teacher gave stimuli by saying "gimana kalau ini dulu?" and the students asnwered "iya". On the contrary, there were two groups that showed a great discussion. They showed logical reasoning which drawing belonged to which page.

Deciding the cover

In deciding the cover the students shared responsibilities to draw a picture and contributed one picture as part of the cover of the book. In one group it showed that there were student who drew fruit, drew the people who was going to eat the food, wrote the title of the book, and colored the cover. There was also groups who decided to have the same drawing to contribute to the cover but different in size. Furthermore, there was one group in which one of the students came up with the idea of having a character of princess on the cover as she liked the character very much while others drew the food.

The data from the interview with the teacher let out that the teacher had a hard time to make the students hold a discussion. Especially when the students should work with the peers they rarely get acquinted. At first, some students objected it but then they enjoyed it. The teacher said that she should give more stimuli in some groups and share attention in one shot. It was exhausted but fun. Fortunately, the teacher admitted that the second and third meeting was running smoother as the students knew thay had some information to discuss with others and also help others in finishing the project.The students also proud to have their drawing would be part of a book. 


\section{Conclusions}

It is concluded that the study showed the students worked together in creating the book. It was seen from the three problems to work on; deciding book title, sharing responsibilities of deciding the flow of the book and deciding the book cover. They engaged to the deep learning subconciously through the book project they should work on. The students showed how they should appreciate other arguments and they practiced to give reasons to their arguments in order to be accepted by others. The study also revealed that teacher experienced a hard work in the first meeting but then it went smoother in the second and third meeting.

\section{Acknowledgments}

This research is funded by Elementary School Teacher Training (PGSD) study program of Universitas Pendidikan Indonesia (UPI) Cibiru Campus. We were very grateful that the research continued to have support from the study program. We would also like to extend our gratitude to 50 students of SD Laboratorium UPI Cibiru Campus grade one; Saturn class and Jupiter class, academic year 2018-2019 who were involved in the study. Finally, we would like to extend our sincere thanks to the teacher Cindy Febilia Valentin for great contribution to the study. She shared time, experiences, ideas, and stories with us. You have made this truly deep learning experiences for us all.

\section{References}

Agesti, M., Ananthia, W., Muliasari, D. N., Harun, C. A., \& Silawati, E. (2018). Child's Sundanese story dictation: A case study of a 5-year-old Indonesian child. Early Childhood Research Journal, 01(1), 29-38.

Ahsan. (2005). Implementing Project-based Learning In Computer classroom. The Turkish Online Journal Education of Technology - TOJET., 4(3).

Ananthia, W., Harun, C. A., Muliasari, D. N., \& Solawati, E. (2017). Experiental learning of future teachers in story dictation for early childhood education. In proceedings of the Tenth Conference on Applied Linguistics and the Second English Language Teaching and Technology Conference in collaboration with the First International Conference, on Language, Literature, Culture, and Education (CONAPLIN and ICOLITE 2007). Literacy, Culture, and Technology in Language Pedagogy and Use, 393-398.

Brewster, J., Ellis, G., \& Girard, D., 2002. The primary English teacher's guide. London: Penguin.

Christ, T., Wang, X. C. \& Chiu, M. M. (2011). Using story dictation to support young children's vocabulary development: Outcomes and Process. Early Childhood Research Quarterly, 26, 30-41.

Creswell, J. W. (2009). Qualitative, quantitative, and mixed method approaches (third ed.). Thousand Oaks: Sage Publications, Inc.

Denzin, N. K., \& Lincoln, Y. S. (2000). Introduction: The discipline and practice of qualitative research. In N. K. Denzin \& Y. S. Lincoln (Eds.), Handbook of qualitative research ( $2^{\text {nd }}$ ed.). Thousand Oaks: Sage Publications, Inc.

Duke, N. K., Havorsen, A. L., \& Strachan, S. L. (2016). Project based learning not just for STEM anymore. Kappan, 98(1), 15-19.

Fullan, M \& Langwothy,M. (2014). Rich Steam: How new pedagogies find deep learning. London: Pearson

Gadzikowski, A. (2007). Story dictation: A guide for early childhood professionals. St. Paul: Redleaf Press.

Hung, C. M., Hwang, G. J., \& Huang, I. (2012). Project-based digital storytelling approach for improving students learning motivation, problem-solving competence and learning achievement. Educational Technology \& Society, 15(4), 368-379. 
Kemendikbud (2014). Materi Pelatihan Implementasi kurikulum2013. Jakarta:Kemendikbud.

Kokotsaki, D., Menzies, V. \& Wiggins, A. 2016. "Project-based Learning: A Review of the Literature" . Improving School, Vol. 19 (3) 267-277.

McMillan, J. H., \& Schumacher, S. (2010). Research in Education: Evidence-based inquiry (seventh ed.). Upper Saddle River: Pearson Education, Inc.

Merriam, S. B. (1998). Qualitative research and case study applications in education: Revised and expanded from Case Study Research in Education. San Francisco: Jossey-Bass.

Merriam, S. B. (2002). Introduction to qualitative research. In S. B. Merriam (Ed.), Qualitative research in practice: Examples for discussion and analysis. San Francisco: Jossey-Bass.

Merriam, S. B. (2009). Qualitative research: A guide to design and implementation. San Francisco: JosseyBass.

Muliasari, Desiani N. (2017). Promoting Critical Thinking through Children's experiential Learning. Proceeding of the 3rd of Iternational Conference of Early Childhood Education. ASSEHR Vol.58.

Ohlsson, Stellan. (2011). Deep Learning: How the Mind Override Experience. Cambridge University Press

Roche, M. (2015). Developing children's critical thinking through picturebooks. New York: Routledge.

Ruwaida, G. A., Harun, C. A., Silawati, E., Ananthia, W., \& Muliasari, D. N. (2018). Story project in the context of early childhood education in Indonesia. Proceeding of International Conference on Child-Friendly Education, Muhammadiyah Surakarta University, April 21 $1^{\text {st }} 22^{\text {nd }}$ 2018, 461-466.

Tan, gregory, J.S. (2013). Promoting Deep Learning with PBL. Proceeding of the 4th International Research Symposium (IRSPBL). Australia

Wrigley, H.S. (2003). Knowledge in Action : The promise of Project Based Learning, Focus and Basic Journal. Vol.2.h.3 